\title{
Analysis and Research on prefabricated building technology based on green low carbon environmental protection
}

\author{
Wenjie Ni ${ }^{\text {a }}$ \\ Gannan University of Science and Technology, Jiangxi Ganzhou, 341000, China
}

\begin{abstract}
With the continuous progress of socialist construction, urban development is changing with each passing day, and various construction projects are continuously completed. At present, the State advocates low-carbon environmental protection and pays attention to ecological stability. Therefore, urbanization construction needs to be carried out under the concept of low-carbon environmental protection. The past construction technology has exposed many deficiencies in the continuous development and construction, such as serious waste of resources, neglect of environmental protection and low production efficiency, which has seriously hindered the transformation and development of the construction field, Prefabricated building technology has the characteristics of resource intensive, green environmental protection and high technical content, which perfectly meets the requirements of the development of the times. In the development of the times, prefabricated buildings gradually appear in people's sight, and are widely recognized by the public because of their green environmental protection, resource intensive and high technical content. Based on this, this paper mainly studies the prefabricated building technology under the current background of Green Low Carbon Environmental Protection.
\end{abstract}

Keywords: Green low carbon environmental protection; Prefabricated building; Green building.

\section{Introduction}

Since the 21st century, with the rapid development of China's construction industry, the scale of the construction industry has continued to expand, and a large number of laborers transferred from rural areas have joined the construction industry. The rapid development of the construction industry has contributed to the development of society and the construction of the economy. And the improvement of people's livelihood has made important contributions [1]. However, it should be noted that the rapid development of the construction industry consumes huge natural resources and has also caused certain damage to China's environment. The rapid development of the construction industry has caused the air quality to continue to decline, affecting people's daily life and health. Based on the current situation, the concept of realizing the green and sustainable development of the construction industry has gradually become popular [2]. The development of prefabricated buildings is still in its infancy. As a representative of building industrialization, we can see from the policies of the State Council and local governments that it is the national development goal to make "house components" flow on the assembly line and form the process of "building blocks" to build houses. As an efficient construction mode, The production mode of prefabricated buildings represents the development direction of construction industry in the future [3].
Assembly-type building is different from the previous building forms. Instead of completing the components in the construction site, it adopts prefabricated form, which is designed and constructed in advance, and then transported to the construction site after completion. The construction site only needs to complete the relevant assembly work. This way realizes the streamlined production of building construction, greatly improves the work efficiency of construction personnel, and at the same time reduces their workload and effectively reduces the construction cost [4]. The application of low-carbon concept makes prefabricated building technology more energy-saving and environment-friendly, and becomes the main development direction of modern building construction [5]. At present, China's prefabricated construction technology still needs further development, and the development of related research work still needs to be strengthened. It is necessary for related workers to carry forward the spirit of hard work and stand hard work and continue to study, so as to improve the quality of China's construction projects [6]. Traditional building forms are all the components needed to complete the construction project at the construction site, but the prefabricated building is different. It refers to the use of the form of appointment to produce the components. After the production is completed, it is transported to the construction site and then assembled according to the

${ }^{\mathrm{a}}$ ni007sd@163.com 
procedure. Components, and then realize the construction of the entire building [7]. In terms of advantages, prefabricated buildings prefer the construction form of flow production, which is not only conducive to the improvement of the work efficiency of constructors, but also effectively reduce the resource cost of construction [8]. In terms of environmental protection, it also minimizes the damage of construction projects to the environment, thus avoiding the problem of pollution to the environment, effectively implements the concept of green low carbon environmental protection, and further promotes the development of prefabricated buildings in a more green and environmental protection direction [9].

\section{Application of Low Carbon and Environmental Protection in Assembly Building Design}

\subsection{Advantages and disadvantages of prefabricated buildings}

Advantages:

Prefabricated buildings are formed by mechanized production of prefabricated components in factories and installation on site. Because standardized production is adopted, prefabricated components can be processed by flow process, which can not only ensure the production speed, but also effectively ensure the continuity of supply. Moreover, prefabricated members only need to command the construction of structural nodes when they faint, which reduces the construction difficulty and workload to a certain extent, and reduces the waste of components generated on site [10]. Prefabricated building construction adopts factory centralized production and unified transportation, so that the concrete mix ratio, cement mortar mix ratio and the number of steel bars are controlled more accurately, and the pollution caused by concrete is reduced. As the prefabricated building uses integrated, integrated and integrated precast concrete components, the wet operation of the formwork on site can reduce various pollution phenomena that often occur in traditional building construction to a certain extent, and can reduce To a certain extent, the cement mortar operation is saved, and the cleanliness of the construction site is effectively improved [11]. Prefabricated buildings can effectively reduce material stacking, loading and unloading, so as to reduce the impact of dust on the surrounding environment. Prefabricated buildings convert most of the on-site construction to factory processing, which can help reduce the discharge of solid waste and sewage, reduce dust and noise pollution, and be conducive to environmental protection [12].

Disadvantages:

At present, there is a lack of some targeted laws and regulations at the national level, while some binding policies and legal norms have little impact on promoting the development of prefabricated buildings. Because the building industrialization is still in the primary stage, the government has not issued specific incentive policies, which restricts the development of large enterprises and the progress of building industrialization [13]. In order to improve the construction efficiency of prefabricated components, it is necessary to have stronger substitutability and universality, and government departments and research institutes at all levels also need to increase the research on standardization, modularization and serialization of components. Due to the large one-time investment in the construction of the prefabricated component factory, and the small market demand at this stage, the component amortization cost is high [14]. The current construction industry management system and talent training mechanism cannot meet the needs of this aspect. Basically, universities and colleges across the country have not set up "prefabricated component" majors, nor have they opened up channels for training skilled workers.

Compared with traditional buildings, the production mode of prefabricated buildings has various obvious advantages, such as building safety and quality, personnel, construction period, environmental protection, etc. see Table 1 for details.

Table 1 Comparison of production methods of prefabricated buildings and traditional building production methods

\begin{tabular}{|c|c|c|}
\hline Compare content & Traditional building & Prefabricated building \\
\hline $\begin{array}{l}\text { Engineering quality } \\
\text { and construction } \\
\text { safety }\end{array}$ & $\begin{array}{l}\text { The open-air } \\
\text { construction } \\
\text { environment has } \\
\text { greatly restricted the } \\
\text { improvement of the } \\
\text { quality of engineering } \\
\text { projects, and the } \\
\text { characteristics of } \\
\text { high-altitude } \\
\text { operations will } \\
\text { increase the incidence } \\
\text { of safety accidents }\end{array}$ & $\begin{array}{l}\text { The parts and components are } \\
\text { uniformly mass-produced in } \\
\text { advance in the factory, which } \\
\text { can more conveniently and } \\
\text { effectively control quality } \\
\text { problems, reduce high- } \\
\text { altitude operations, greatly } \\
\text { reduce safety benefits, and } \\
\text { ensure construction safety }\end{array}$ \\
\hline Construction period & $\begin{array}{c}\text { The construction } \\
\text { period is long, and it } \\
\text { is greatly affected by } \\
\text { the external } \\
\text { environment such as } \\
\text { natural environment, } \\
\text { and cross-operations } \\
\text { cannot be realized } \\
\text { between various } \\
\text { majors }\end{array}$ & $\begin{array}{l}\text { A large number of parts and } \\
\text { components are prefabricated } \\
\text { in the factory, which is not } \\
\text { affected by weather and } \\
\text { temperature; various } \\
\text { professional constructions can } \\
\text { achieve three-dimensional } \\
\text { crossover operations, which } \\
\text { greatly reduces the } \\
\text { construction period }\end{array}$ \\
\hline Construction staff & $\begin{array}{l}\text { The number of } \\
\text { workers required is } \\
\text { large, the stability of } \\
\text { personnel is poor, and } \\
\text { the professional level } \\
\text { is different, which } \\
\text { increases the difficulty } \\
\text { of management }\end{array}$ & $\begin{array}{l}\text { The high degree of } \\
\text { mechanized operation has } \\
\text { greatly reduced the number of } \\
\text { workers required, but the } \\
\text { requirements for the } \\
\text { professionalization of workers } \\
\text { have increased }\end{array}$ \\
\hline Labor productivity & $\begin{array}{l}\text { Low labor } \\
\text { productivity: using } \\
\text { traditional wet } \\
\text { methods }\end{array}$ & $\begin{array}{l}\text { High production efficiency: } \\
\text { parts and components are } \\
\text { prefabricated by the factory in } \\
\text { batches, and on-site } \\
\text { mechanized construction }\end{array}$ \\
\hline $\begin{array}{l}\text { Energy saving and } \\
\text { environmental } \\
\text { protection }\end{array}$ & & $\begin{array}{l}\text { The construction site is clean } \\
\text { and tidy, produces less } \\
\text { construction waste, and has a } \\
\text { higher recovery rate. The } \\
\text { semi-closed production } \\
\text { environment of the factory } \\
\text { can effectively reduce noise, } \\
\text { dust and other pollution } \\
\text { phenomena }\end{array}$ \\
\hline Building quality & $\begin{array}{l}\text { There is a lot of } \\
\text { construction waste at } \\
\text { the construction site, } \\
\text { and water resources } \\
\text { and noise pollution } \\
\text { are serious. Material } \\
\text { consumption is high, } \\
\text { and it is easy to } \\
\text { produce waste }\end{array}$ & $\begin{array}{l}\text { The prefabricated production } \\
\text { of parts and components } \\
\text { mainly relies on the } \\
\text { mechanized numerical control } \\
\text { equipment in the factory, } \\
\text { which can ensure the } \\
\text { accuracy of the components, } \\
\text { thereby greatly improving the } \\
\text { quality of the building. And } \\
\text { the parts produced are better } \\
\text { in terms of impermeability, } \\
\text { etc. }\end{array}$ \\
\hline
\end{tabular}




\subsection{Embodiment of low carbon environmental protection in prefabricated building design}

The prefabricated building technology based on the concept of low-carbon and environmental protection requires comprehensive consideration at the beginning of the design. First of all, through scientific design, the building takes away indoor heat through the flow of natural wind, instead of artificial means such as air conditioners and electric fans, so as to create a comfortable indoor environment. Figure 1 shows the design of green, ecological and environmentally friendly buildings.

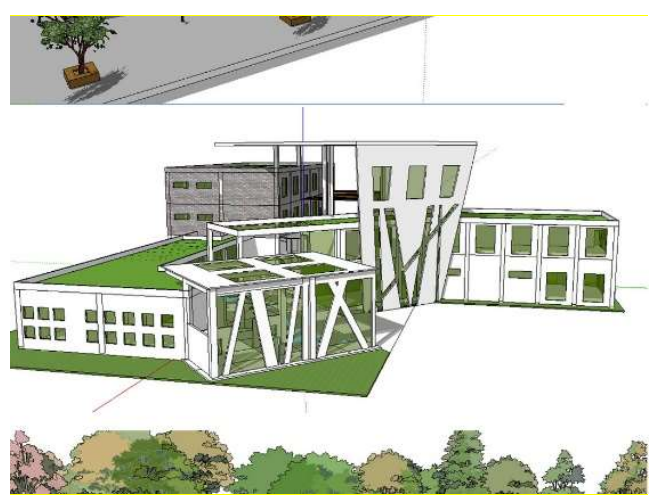

Figure 1 Green ecological and environmental protection building design

Secondly, water resources in construction projects can also be reduced by reasonable water supply and drainage design, and solar energy can be used for water heating and power generation. Finally, the energy utilization in the construction project can be replaced by new clean energy, so as to effectively control greenhouse gas emissions [15]. Unreasonable design of prefabricated buildings will lead to poor indoor air circulation, resulting in indoor air pollution, and long-term living will be harmful to the body. Ideally, a permeable north-south indoor layout will make the indoor air unblocked. However, the current city has a small amount of land and it is difficult to achieve such an indoor layout. In this case, the indoor walls and spaces can be rationally laid out. Enhance the circulation of indoor air and the entry of light. For example, designing a ceiling in the interior can appropriately reduce the indoor space, thereby effectively reducing the consumption of resources, and at the same time increasing the indoor thermal insulation efficiency.

Different scholars have different views on the theory of technological innovation process. Many scholars at home and abroad have put forward many models about technological innovation process and technology promotion model from different angles. This model points out that technological innovation mainly covers several stages, such as research and development, production and marketing. Technological innovation begins with scientific R \&amp; D and technological creation, and finally the market through the continuous development of enterprise technology. The realization of technological innovation is inseparable from the application of innovative achievements such as new technologies and new products developed by enterprises in the laboratory.
In other words, the market receives the enterprise's new technology, and the customer is the passive recipient. Only by investing enough factor resources in the innovation process, the enterprise will have more opportunities to carry out technological innovation, and the possibility of innovation success will be greater. The model is shown in Fig. 2.

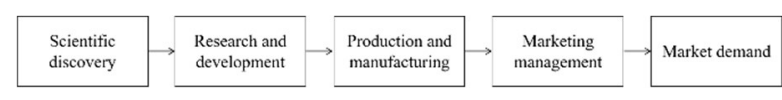

Fig. 2 Technology promotion model

\section{Prefabricated building technology based on Green low carbon environmental protection}

\subsection{Dynamic scheduling in prefabricated buildings}

In the process of assembly construction, if the useful information needed by construction scheduling can not be fed back to the scheduling system in time, it will lead to the scheduling system failing to make timely and accurate response according to the actual construction state and produce errors. A complete assembly construction process should involve three links, namely, construction preparation, construction scheduling and construction execution, in which construction data are continuously generated and exchanged. As shown in Fig. 3.

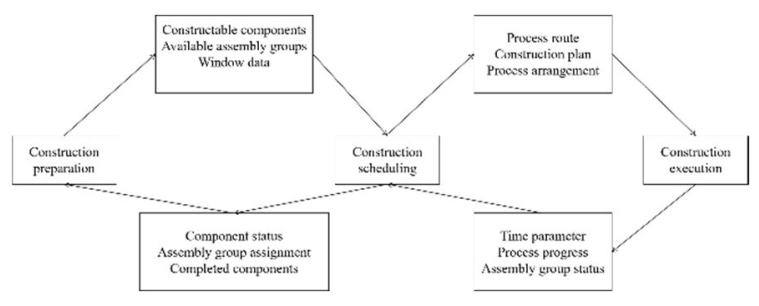

Fig. 3. Data flow chart

The construction process of prefabricated buildings involves multiple building components and multiple processes, and multiple assembly groups are required to complete the construction at the same time. Therefore, it is necessary to coordinate the building components, assembly processes, and assembly groups, and optimize the optimization goals by rationally arranging the resources between each component. The mathematical model of prefabricated building schedule optimization can be described as: suppose there are a total of $\mathrm{n}$ building components, and each component has $\mathrm{k}$ assembly procedures. These $\mathrm{k}$ procedures are constructed by an assembly group of $m$ different components composed of several people. There are $\mathrm{x}$ types of groups, and each type contains different assembly groups. The objective function of the schedule optimization problem is to find the shortest time required to complete all the processes of all building components.

According to the construction characteristics of prefabricated buildings, the main constraints of the 
schedule optimization of prefabricated buildings are shown as follows:

$$
\begin{gathered}
P_{i j}+T_{i j}^{a} \leq C_{i j} \\
C_{i j} \leq P_{i(j+1)} C_{i j} \leq P_{i(j+1)} \\
P_{i j}+T_{i j}^{a} \times W_{i j f g}^{a} \leq P_{f g}+T_{f g}^{a} \times\left(1-W_{i j f g}^{a}\right)
\end{gathered}
$$

Among them, formula (1) and formula (2) represent the front and rear constraints of the process in the same component. The start time and the construction time of a process shall not be greater than its construction completion time, and the construction completion time of any process of the same component shall not be greater than the start time of its next process. Formula (3) indicates the sequence constraint between different component processes in the same assembly group, and the completion time of a component process in the assembly group should not be greater than the start time of another component process in the assembly group. The purpose of this paper is to use scheduling strategies to optimize the construction schedule of the project and minimize the maximum completion time. Therefore, for the evaluation of the pros and cons of the scheduling strategy of prefabricated buildings, this paper will take the minimization of the maximum completion time as the goal and establish an objective function. The function expression is:

$$
C=\min \left(\max _{l \leq i \leq n, l \leq j \leq k} C_{i j}\right) C=\min \left(\max _{l \leq i \leq n, l \leq j \leq k} C_{i j}\right) \text { (4) }
$$

Among them, $\max _{l \leq i \leq n, l \leq j \leq k} C_{i j}$ represents the largest one of the time when all components complete the last process.

\subsection{The main features of Green low carbon environmental protection in prefabricated buildings}

In terms of prefabricated buildings, the opinions on promoting the sustainable and healthy development of the construction industry issued by the general office of the State Council on February 17, 2017 clearly proposed to promote prefabricated buildings, adhere to standardized design, industrialized production, prefabricated construction, information management and intelligent application, promote the innovation of construction methods and vigorously develop prefabricated concrete buildings, Strive to increase the proportion of prefabricated buildings in new buildings to $30 \%$ within 10 years.

According to the statistics of the Ministry of Housing and Urban-Rural Development, as shown in Table 2, in 2015, the newly-built prefabricated building area in China was 73.7 million square meters, accounting for $2.9 \%$ of the newly-built urban building area. In 2016, the newly built prefabricated building area was 125 million square meters, accounting for $5.2 \%$ of the newly built urban building area, an increase of $57 \%$ compared with 2015 . From January to October, 2017, about 130 million square meters of prefabricated buildings have been built nationwide.
Table 2 Analysis of the development of prefabricated buildings from 2015 to October 2017

\begin{tabular}{|c|c|c|c|}
\hline Time & $\begin{array}{c}\text { Newly built } \\
\text { prefabricated } \\
\text { building area } \\
\text { (ten } \\
\text { thousand } \\
\text { square } \\
\text { meters) }\end{array}$ & $\begin{array}{c}\text { Growth rate } \\
\text { of newly } \\
\text { built } \\
\text { prefabricated } \\
\text { building area } \\
(\%)\end{array}$ & $\begin{array}{c}\text { Percentage } \\
\text { of newly } \\
\text { built } \\
\text { building } \\
\text { area (\%) }\end{array}$ \\
\hline 2015 & 7370 & - & 2.9 \\
\hline 2016 & 12500 & 62 & 5.2 \\
\hline $\begin{array}{c}\text { January- } \\
\text { October } \\
2017\end{array}$ & 13000 & - & \\
\hline
\end{tabular}

In November 2017, the Ministry of Housing and UrbanRural Development announced the first batch of prefabricated building demonstration cities and industrial bases for prefabricated buildings. As shown in Table 3, 30 cities including Beijing and Hangzhou were identified as the first batch of prefabricated building demonstration cities. 195 companies including Beijing Zhuzong Group Co., Ltd. and Hangxiao Steel Structure Co., Ltd. are the first batch of prefabricated building demonstration industrial bases.

Table 3 Fabricated building industry development analysis table

\begin{tabular}{|c|c|c|c|}
\hline Time & $\begin{array}{c}\text { Newly built } \\
\text { assembly- } \\
\text { type } \\
\text { demonstratio } \\
\text { n cities (one) }\end{array}$ & $\begin{array}{c}\text { Assembled } \\
\text { constructio } \\
\text { n industrial } \\
\text { base (one) }\end{array}$ & $\begin{array}{c}\text { Demonstratio } \\
\text { n project of } \\
\text { prefabricated } \\
\text { buildings } \\
\text { (one) }\end{array}$ \\
\hline $\begin{array}{c}\text { November } \\
2017\end{array}$ & 40 & 195 & - \\
\hline 2020 & 70 & 59 & 510 \\
\hline $\begin{array}{c}\text { Completio } \\
\text { n rate (\%) }\end{array}$ & 60 & 98.2 & - \\
\hline
\end{tabular}

Different from previous buildings, the exterior wall design of prefabricated buildings can better meet the requirements of residents. According to different changes in region, climate and temperature, the exterior wall of prefabricated buildings can not only retain personalization, but also have energy-saving effect better than traditional buildings. In the roof structure design of prefabricated buildings, the commonly used structural types are waterproof panel, thermal insulation panel, etc. load materials such as thermal insulation roof board and cement composite board are the main construction materials of roof structure.

Use information software for spatial modeling to improve the fineness of interior design. As shown in Figure 4. 


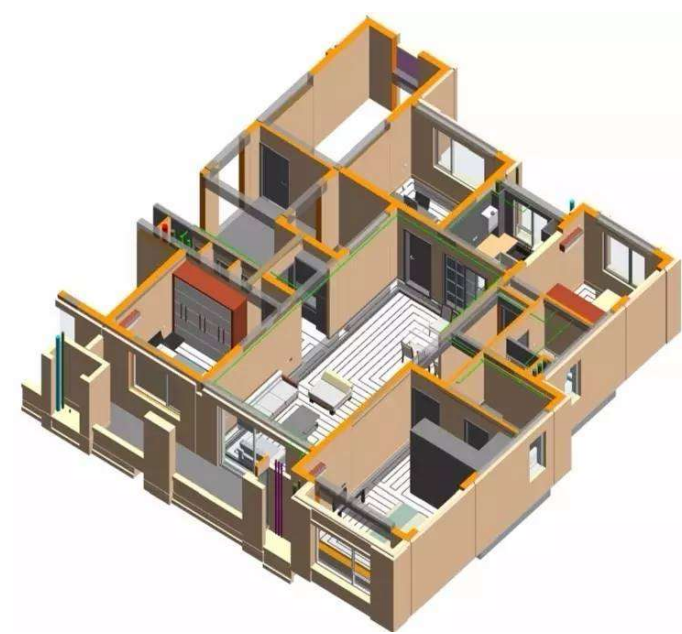

Figure 4. Prefabricated building design

In addition to the wall surface, the exterior windows of prefabricated buildings have also changed. In the construction of exterior windows, we can no longer rely solely on the traditional single-layer glass, and we need to choose double-layer hollow plastic-steel window glass to satisfy the use of exterior windows of prefabricated buildings and achieve better thermal insulation effect. At the same time, the floor treatment of prefabricated buildings is quite different from that of previous buildings, and it is necessary to consider the suitable materials needed for different floor thicknesses in the selection of materials.

The operation and management process of green buildings touches on many aspects of building envelope, water supply and drainage, HVAC, electrical, renewable energy, environmental greening, garbage disposal, traffic safety, etc. The following two points are mainly used for renewable energy and measurement and testing equipment. There are many differences with traditional buildings, and more standardized requirements are put forward for operation and management. Therefore, these two requirements are listed as special items. The technical content includes the operation and maintenance of renewable energy and measurement and testing equipment, optimization, and data collection and analysis of testing equipment.

\section{Conclusions}

In the current social development, the advancement of urbanization requires people to have more and more demand for buildings. They not only need buildings to have more functions, but also pay more attention to green energy conservation and environmental protection. Prefabricated building is an important product that more conforms to the development of the concept of green, lowcarbon and environmental protection in the current era. The building method based on prefabricated components and assembly can not only effectively reduce the loss of energy and the waste of construction cost, but also reduce the generation of construction waste. The use of green, low-carbon and energy-saving building materials further realizes the protection of the environment. Assembly-type green building is a relatively environmentally friendly, systematic and integrated way. In order to protect the environmental resources we have now, we must adopt green, reasonable and feasible construction methods. At the same time, in order to meet the standards of building environmental protection, green construction technical measures should also be taken to ensure the quality, quantity and timely completion of the project.

\section{References}

1. Guo Wenlong. Construction technology advantages of concrete prefabricated residential buildings[J]. Building Materials and Decoration, 2019, 000(034): 42-43.

2. Niu Xinchun. Exploring the key technology analysis and quality supervision measures of house building fabricated structure[J]. China Construction, 2020, No.203(02):124-125.

3. Zhang Mengjie. Research on prefabricated steel structure building system based on BIM technology $[\mathrm{J}]$. Building Materials and Decoration, 2019, 567(06):130-131.

4. Zhang Ying. Design and construction of prefabricated concrete structure[J]. China Science and Technology Information, 2018, 000(021):38-40.

5. Chen Liru. On prefabricated buildings-the main force of green buildings[J]. Building Development, 2020, 4(5):97-98.

6. Lv Yizhe, Ding Jie. The application and breakthrough of green building technology for steel structure prefabricated houses-new strategies for healthy, low-carbon, and smart houses[J]. Architectural Techniques, 2019, No.289(10):120123.

7. Hai Rihan, Zhou Jiaxu, Jia Xiaohu. The expression of the prefabricated architectural concept in the modern new-style yurt design[J]. Industrial Construction, 2020(3): 58-63.

8. Wang Zhenyu. Talking about the construction technology of prefabricated concrete structure of house building $[\mathrm{J}]$. Architecture and Budget, 2020, No.292(08):70-72.

9. $\mathrm{Fu}$ Lei. Application of prefabricated building technology under the background of green building[J]. Green Building Materials, 2020, No.155(01):55+57.

10. Zhao Xiaoni. Application of BIM technology in green construction of prefabricated buildings[J]. Building Materials and Decoration, 2018, 558(49):25-26.

11. Zhang Guoyin. Low-carbon energy-saving prefabricated building technology research[J]. China Housing Facilities, 2020, No.209(10):81-82.

12. Ye Guoren. The application of BIM technology in prefabricated structure $[\mathrm{J}]$. Gansu Science and Technology, 2017, 33(014):85-86. 
13. Ma Xinyi. Application of prefabricated houses in green buildings[J]. Construction Technology Development, 2018, v.45; No.391(13):8-9.

14. Xue Jingdong. Prefabricated buildings: the integration of green and innovative technologies [J]. China Economic Information, 2017, 000(023): 36-37.

15. Wang Jian. Research on low-carbon energy-saving prefabricated building technology[J]. China Construction, 2017, No.151(12):138-139. 